\title{
Strategic Management in National and Chinese Primary School in Malaysia
}

\author{
Jamalullail Abdul Wahab ${ }^{1}$, Aida Hanim A. Hamid ${ }^{1}$, Mohd Izham Mohd Hamzah ${ }^{1}$ \& Nurhasyida Abdullah Sani ${ }^{1}$ \\ ${ }^{1}$ Faculty of Education, Universiti Kebangsaan Malaysia, Selangor, Malaysia \\ Correspondence: Jamalullail Abdul Wahab, Faculty of Education, Universiti Kebangsaan Malaysia, 43600 UKM \\ Bangi, Selangor, Malaysia. E-mail: jamall64@ukm.my
}

\author{
Received: August 1, 2013 Accepted: August 16, 2013 Online Published: August 30, 2013 \\ doi:10.5539/ass.v9n12p44 URL: http://dx.doi.org/10.5539/ass.v9n12p44
}

\begin{abstract}
Strategic management is a set of managerial skills that should be used throughout the organization especially for all school leaders in a wide variety of functions to achieve organizational vision and mission or goals. This study aims to examine the level of practice of strategic management among the school administrators of National Primary School and Chinese Primary School in Seremban, Malaysia, in 12 aspects of school management. A total of 30 teachers from National Primary School and 30 teachers from Chinese Primary School were taken as respondents in this study. The instrument used in this research was questionnaires and the analysis of this quantitative data employed descriptive statistics and inferential statistics. The result of the study showed that there was a significant difference based on the types of the school in which the level of practice of strategic management among school administrators in Chinese Primary School was higher than the National Primary School. The findings are useful for school leaders, teachers and all school practitioners as well as policy makers of strategic planning and management issues as well as practices which exist in the twelve aspects studied. Implications for research and practice were discussed.
\end{abstract}

Keywords: strategic management, National primary school, Chinese primary school

\section{Introduction}

Strategic management is a structured and systematic work process framework which interprets the mission, vision and strategy towards daily work activities (Fidler, 2005). Strategic management assists the capability of administrators in measuring effective controlling strategy in achieving the mission and vision of an organization (Berry, 2007). The direction and future of an organization needs to be organized systematically in achieving the required objectives.

According to Rosli (2002), strategic management contributes to organization's accomplishment and excellence. In addition, Burnes (2009) and Choo \& Nick (2002) state that strategic management enables an organization to be more proactive than reactive in forming its future. Salmah (2005) also reaffirms in her study that strategic management has made the management process of a school to be proactive in creating the future phenomena of a school organization.

Administrators are individuals who manage schools and they are responsible in determining the direction to be excellent or otherwise. Abas (2007) states that without learning the skills of strategic management and operational planning, the leaders will only realize that they do not involve in anything except crisis management. Administration that does not have a clear management model will be facing difficulty in managing its organization effectively (Middlewood \& Lumby, 1998; Fidler, 2005). Thus, strategic management in administration will impact the school administrators to take initiative to act as a change in controlling the new situation and creating strategies (Rosli 2002; Berry, 2007; Lunenburg \& Ornstein, 2012). Besides, by implementing the strategic management, the administration of the school will depend on the roles of a leader who is visionary, capable and efficient in handling problems which cover from the management of time to management of conflicts in schools.

In order to realize the vision of the Malaysia Ministry of Education in achieving excellent education system towards the year 2020, the practice of strategic management among the school administrators should be at the maximum level. In addition, strategic management practice among the school administrators is required to 
develop school capacity in dealing with challenges and change (Berry, 2007; Dowling et al., 2008) which happen in the education world regardless whether they are at the local or the global level. Every planning and execution must be based on the vision to bring changes and paradigm shift in terms of way of thinking and the actions of the members in the school.

Schools are always loaded with many problems mainly because of the weak practice of the strategic management among the administrators, teachers, students, local community, parents or the environment itself. The problems which occur in school will have significant impact towards the excellence of that particular school (Dinham 2005). According to David (2009), among the problems that are associated with the school administration are bureaucracy attitude and conflict that occur among the administrators and teachers, imperfection of the school's infrastructure, personnel management and low students' academic performance, the non-conducive of the school climate and the complication within the administration itself.

Many studies on strategic management were implemented in the school level whether it is within the country or abroad. Study that has been done by Marzita (2002) and Azlin (2010) on religious school managers in Selangor found that strategic management does help the school's managers to act proactively towards determining the organizational goals achievement. Rosli (2002) in his research on strategic management among Technical Secondary School in Perak, Malaysia found that the strategic management practice among the school managers are good and produce positive implications towards the excellence of the schools in achieving their mission, vision, and their objectives. Further, there are some aspects of school management systems in which must be handled effectively by the administrators in Malaysia such as administrators' leadership, financial management, discipline management, Parent-Teacher Association (PTA) and local community management, curriculum management, school infrastructural management, staff development management, text books loan scheme management and finally the work performance assessment management.

\section{Methodology}

This study aims to identify the level of practice in strategic management among the administrators of National Primary School and Chinese Primary School in Seremban district from the teachers perspective in the aspects of: (i) Administrators' leadership; (ii) Financial management; (iii) Co-curriculum management; (iv) Discipline management; (v) Curriculum management; (vi) School infrastructure management; (vii) Staff professionalism management; (viii) school's conducive environmental management; (ix) Excellence academic management programme; (x) Text books loan scheme management; and (xi) Work performance assessment management. The objective of this study is to identify whether there are any differences on the practice level of strategic management among the administrators between National Primary School and Chinese Primary School in 12 aspects of school management.

This is a quantitative study which uses the survey method . Data was collected by using questionnaire and then it was analyzed using inferential statistics (t-test). The research respondents consist of a total of 60 teachers in which 30 teachers are from National primary school and others are from Chinese primary school. In this study, the teachers' perspectives on the strategic management practice among the administrators are used to determine the practice level of strategic management in related schools.

The questionnaire consists of the items on the practice level of strategic management in twelve aspects. The twelve aspects which are related to the level of practice in strategic management are the schools' leadership, financial management, co-curriculum management, discipline management, PTA and local community management, curriculum management, infrastructural management, teachers' and staffs' towards professionalism management, conducive environmental management, students' excellence academic management programme, text books loan scheme management and work performance assessment management. Every aspect consist sof 10 items. The items were arranged using Likert Scale 5 Points which has the options according to the level of execution from "Not Practice", "Poorly Practice", "Average Practice", "Good Practice" and "Best Practice". Analysis of the pilot study shows that the value of the Cronbach Alpha for overall items is 0.9648 (Very high).

\section{Results and Findings}

The results are shown in Table 1. 
Table 1. Comparison mean scores on the practice level of strategic management between national primary school and Chinese primary school

\begin{tabular}{|c|c|c|c|c|}
\hline Management Aspects & School Type & $\mathbf{N}$ & Mean & St. Deviation \\
\hline \multirow[t]{2}{*}{ Administrator's Leadership } & SK & 30 & 3.50 & 0.587 \\
\hline & $\operatorname{SJK}(C)$ & 30 & 3.97 & 0.508 \\
\hline \multirow[t]{2}{*}{ Financial Management } & SK & 30 & 3.52 & 0.719 \\
\hline & $\operatorname{SJK}(\mathrm{C})$ & 30 & 4.15 & 0.574 \\
\hline \multirow[t]{2}{*}{ Co-curriculum Management } & SK & 30 & 3.65 & 0.527 \\
\hline & $\operatorname{SJK}(C)$ & 30 & 3.92 & 0.530 \\
\hline \multirow[t]{2}{*}{ Discipline Management } & SK & 30 & 3.51 & 0.745 \\
\hline & $\operatorname{SJK}(C)$ & 30 & 3.74 & 0.472 \\
\hline \multirow[t]{2}{*}{ PTA Management } & SK & 30 & 3.10 & 0.584 \\
\hline & $\operatorname{SJK}(\mathrm{C})$ & 30 & 3.52 & 0.502 \\
\hline \multirow[t]{2}{*}{ Curriculum Management } & SK & 30 & 3.73 & 0.654 \\
\hline & $\operatorname{SJK}(\mathrm{C})$ & 30 & 4.18 & 0.437 \\
\hline \multirow[t]{2}{*}{ Infrastructure Management } & SK & 30 & 3.46 & 0.816 \\
\hline & $\operatorname{SJK}(\mathrm{C})$ & 30 & 3.92 & 0.468 \\
\hline \multirow[t]{2}{*}{ Professionalism Management } & SK & 30 & 3.56 & 0.781 \\
\hline & $\operatorname{SJK}(\mathrm{C})$ & 30 & 3.98 & 0.545 \\
\hline Conducive & SK & 30 & 3.09 & 0.71 \\
\hline Environmental Management & $\operatorname{SJK}(\mathrm{C})$ & 30 & 3.51 & 0.548 \\
\hline \multirow[t]{2}{*}{ Academic Excellence Management } & SK & 30 & 3.32 & 0.785 \\
\hline & $\operatorname{SJK}(\mathrm{C})$ & 30 & 3.56 & 0.551 \\
\hline \multirow[t]{2}{*}{ Text Book Loan Scheme Management } & SK & 30 & 3.92 & 0.626 \\
\hline & $\operatorname{SJK}(\mathrm{C})$ & 30 & 4.27 & 0.618 \\
\hline \multirow[t]{2}{*}{ Performance Assessment Management } & SK & 30 & 3.40 & 0.798 \\
\hline & $\operatorname{SJK}(\mathrm{C})$ & 30 & 3.85 & 0.552 \\
\hline
\end{tabular}

Note: SK= National School, SJK(C) $=$ Chinese Primary School

Based on Table 1.0, the mean score for all 12 aspects management (administrators' leadership, financial management, co-curriculum management, discipline management, PTA Management, curriculum management, infrastructural management, teachers' and staffs' professionalism management, conducive environmental management, academic excellence management, Text Book Loan Scheme management, performance assessment management) among the administrators' in Chinese Primary School is higher compared to National Primary School. Although the level of practice is average but the differences of the mean score shows that the level of practice in strategic management among administrators is slightly higher in Chinese Primary School as compared to National Primary School.

Overall, the comparison of the mean scores for the level of practice in the twelve aspects of strategic management among administrators in Chinese Primary School is higher than National Primary School (Table 2).

Table 2. Comparison of the overall means scores on the level of practice in strategic management between national primary school and Chinese primary school

\begin{tabular}{llll}
\hline School Type & N & Mean & Standard Deviation \\
\hline SK & 30 & 3.4801 & 0.588 \\
SJK $(C)$ & 30 & 3.8715 & 0.408 \\
\hline
\end{tabular}

Note: SK= National School, SJK(C) $=$ Chinese Primary School 
Based on Table 2.0, it is found that the overall $\mathrm{t}$ value for the comparison on the level of practice in strategic management on the 12 aspects of management is $t=-2.993$ and the $p$ significance level $=0.004$. This significance level is slightly lower than $0.05(\mathrm{p}<0.05)$. This shows that there are significant differences on the level of practice in twelve aspects of strategic management among the administrators of both schools.

The mean scores for the level of practice in the twelve aspects of strategic management among the administrators (3.8715) is higher in Chinese Primary School than the mean scores from National Primary School (3.4801).

\section{Discussion}

This research finding indicates that there are significant differences on the mean scores from the twelve aspects of the level of practice in strategic management between the National Primary School and Chinese Primary School in which the mean score on the level of practice in strategic management is higher in Chinese Primary School as compared to National Primary School. This research finding is also parallel with Ghazali (2001) and Abas (2007) who state that the education system in Chinese Primary School is well organized, creative in teaching and follows current development. Teachers in Chinese Primary School are also said to be more strategic in their job (Peow, 2011) whereas teachers in National Primary School are said to be solely dependable on syllabus and circular from the Ministry of Education (Ghazali, 2001; Abas, 2007)). Chinese Primary School is said to have a strong work culture and more advance on the area of Science and Mathematics in term of its quality (Peow, 2011) that leads non-Chinese students' enrollment in the Chinese Primary school to increase (Yung-peng, Chi-chung \& Ngai-ying, 2006). This gives a picture that the management in Chinese Primary School is more strategic which leads to more Malay parents to send their children to Chinese medium school and feel confident in the learning system in Chinese school which could help to increase their children's level of academic excellence.

According to Abas (2007) and Berry (2007), an organization such as school is indeed must apply strategic management comprehensively and collectively in determining the success or failure of that organization. The roles and the strategic management skills are important in school management nowadays (Rosli, 2002; Norazlin, 2010; Lunenburg \& Ornstein, 2012). From the aspect of leadership, education organization should have condensed management in the aspects of analyzing external environment, men's leadership, structure, technology, politic, culture and education (Caldwell, 2004; Anderson, 2009). A leader that is efficient in planning, implementing, determining the direction, controlling and able to analyze every changes that happen is the leader that is needed (Burnes, 2009).

In term of financial management aspect, besides spending provision that is given by the Malaysia Ministry of Education, administrators should plan strategically on the activities that could bring in funds to schools such as organizing Entrepreneurial Day. Administrators that think and act strategically will bring profit to schools and not only depending on the provision from the Malaysia Ministry of Education. The State Education Department which is under the Malaysia Ministry of Education should design a course to train school's administrators to become entrepreneurs so that they are able to think in strategic ways of how to increase the schools' funds so that all programmes could be executed as planned.

From the aspect of co-curriculum management, students' talent must be developed at the optimum level and comprehensively in sports activities, clubs and uniform units not only at the school level but to higher level. The Malaysia's Ministry of Education must plan strategically in choosing talented students from primary schools and give them the appropriate guidance and trainings until they can succeed at the national level so that the training process does not stop at the primary school level and these students do not lose focus and waste their talent. Teachers must also be given rights in attending courses or seminars in order to enhance the quality of sports activities, clubs and uniform units.

Discipline problems that are difficult to curb will make the school's climate to be non-conducive for the teaching and learning processes. The schools' administrators should be able to handle the students discipline problems strategically with various ways such as to organize discipline alliances among the PTAs and community level, to reinforce the schools' rules continuously, to conduct awareness talk programmes such as talks from the police unit, juvenile talks and anti drug talks and giving recognition continuously and significantly to students who have changed to more positive attitudes.

There is a need to increase the level of practice in strategic management from the aspect of PTA and the local community. Alliance between parents and schools will give many benefits to the students. The success of parental involvement in school education requires systematic and strategic efforts through comprehensive planning and multi-level management. There should be a framework for development and practice in parental involvement in education which could provide school practitioners and change agents a more comprehensive 
model to plan, manage, and implement effective parental involvement in school education.

To increase the practice level of strategic management in the aspect of curriculum, school administrators need to be strategic in choosing the subject panel chairperson based on experiences and work quality of a teacher. This is vital for the subject panel chairperson to plan relevant, effective and useful academic programmes for students so that it will help to increase the teaching and learning process. The school administrators should also monitor the panel activities so that it is consistent with the mission and the vision of the school. The State Education Department should design a course that could enable these teachers to plan curriculum activities by using methods and creative materials in the teaching and learning process. Teachers should be given the permission to attend courses that are related to ICT through seminars and workshop in computer literacy.

The practice level of school infrastructure management could also be enhanced by the action of administrators in practicing strategic management to make sure that students' need of learning is sufficient so that the learning process is not interrupted. Administrators must be sensitive to equipment that are provided by the Malaysia`s Ministry of Education by ensuring that these equipment are good care and they are used at the optimum level to avoid wastage and damage.

The school administrators through various approaches should give encouragement in organizing continuing professional development programmes among teachers and staffs with appropriate frequency. This could also enhance teachers and staffs towards professionalism management. Every programme that is executed must have a monitored and improvement process so that staffs and teachers could utilize it at maximum level in their teaching and learning process in school.

In the aspect of school conducive environmental management, the practice levels of strategic management for both schools are at average levels. Administrators should strategically practice a few programmes that could enable school members to work collaboratively in improving the schools' environment. Among the programmes that could be practiced by the administrators are by organizing cleanliness competition, conducting collaborative activities and improving schools' development projects. Administrators must ensure that every programme that is planned is strategic in making the school compound to be clean and conducive. Administrators could even participate in beautifying school competitions at the national level in order to motivate all school members to make sure that their schools are always in clean, beautiful and conducive. The Malaysian Ministry of Education is recommended to make all beautiful schools as their icon schools by giving rewards and incentives for their efforts.

The administrators could also improve the practice level of strategic management in the aspect of school academic excellence by creating strategic management framework on how to improve students' academic excellence. For example, administrators could plan by organizing additional class programme, remedial classes and mentor-mentee programme for students to enhance their achievement.

For the aspect of performance assessment management, the level practice of strategic management is also average for both schools. To reduce the discontentment of teachers who have high expectation on the process of performance assessment, the practice on strategic management must be improved. Administrators must always discuss and evaluate fairly in the form of participative management. Besides that, administrators must cultivate strategic work system and effective communication in schools.

Malaysia's Ministry of Education is recommended to monitor and give continuous encouragement on strategic management in all aspects of school management, especially for those primary schools that do not achieve the required level of strategic school management. Primary schools in the Seremban district have the potential in practicing strategic management at a better level if both the State Education Department and the Ministry of Education are able to give them proper attention and appropriate monitoring. The practice level of strategic management among the administrators in Chinese Primary School is higher compared to National Primary School due to the pressure and the support given by the Chinese community by practicing quality strategic management to fulfill the needs on their children's education.

\section{References}

Abas, A. (2005). Empowering instructional leadership (Memperkasa kepimpinan instruksional). KPM, Kuala Lumpur.

Anderson, G. L. (2009). Advocacy leadership. Routledge, New York.

Berry, F. S. (2007). Strategic planning as a tool for managing organizational change. International Journal of Public Administration, 30(3), 331-346. http://dx.doi.org/10.1080/01900690601117812 
Burnes, B. (2009). Managing Change (5th ed.). Prentice Hall, London.

Caldwell, B. J. (2004). Re-imagining the self-managing school. Special Schools Trust, London.

Choo, C. W., \& Nick, B. (2000). The strategic management of intellectual capital and organizational knowledge. Oxford University Press, London.

David, F. R. (2009). Concepts of strategic management (12th ed.). Prentice Hall, New Jersey.

Dinham, S. (2005). Principal leadership for outstanding educational outcomes. Journal of Educational Administration, 43(4), 338-356. http://dx.doi.org/10.1108/09578230510605405

Dowling, P. J., Festing, M., \& Engle, A. D., (2008). International human resource management (5th ed.). London: Thomas Learning.

Fidler, B. (2005). Strategic management for school development. Paul Chapman, London.

Ghazali, O. (2001). Sekolah Berkesan dan program pembaikan sekolah di Malaysia. Educators Digest, 1(2).

Lunenburg, F. C., \& Ornstein, A. C. (2012). Educational administration. Concepts \& practices (6th ed.). Linda Schrelber-Ganster, Belmont, USA.

Marzita, A. B. (2002). Strategic management among religious schools' managers in Selangor (Pengurusan strategik di kalangan pengurus sekolah agama di Selangor). Thesis of Master Degree, Universiti Malaya.

Middlewood, D., \& Lumby, J. (1998). Strategic management in schools and colleges. Paul Chapman, London.

Norazlin. (2010). Strategic management in Selangor state religious schools (Pengurusan strategik di sekolah agama negeri Selangor). Thesis of Master Degree, Universiti Kebangsaan Malaysia.

Peow, S. H. (2011). Golbalization and the Malaysia experience: Upsides and downsides. Journal of Asia Pacific Studies, 2(1), 1-27.

Rosli, S. (2002). Strategic management among managers Technical School in Perak (Pengurusan strategik dalam kalangan pengurus Sekolah Menengah Teknik di negeri Perak). Kertas Projek Sarjana. Universiti Malaya.

Salmah, S. (2005). Strategic management among managers Technical School in Perak (Pengurusan strategik di kalangan pentadbir sekolah Kebangsaan di daerah Hilir Perak). Thesis of Master Degree, Universiti Malaya.

Thomson, J., \& Martin, F. (2010). Strategic management (6th ed.). Thomas Rennie, Hamshire.

Yun-peng, L., Chi-chung, L., \& Ngai-ying, W. (2006). Chinese primary school mathematics teachers working in a centralised curriculum system: a case study of two primary schools in North-East China. A Journal of Comparative and International Education, 36(2), 197-212. http://dx.doi.org/10.1080/03057920600741206

\section{Copyrights}

Copyright for this article is retained by the author(s), with first publication rights granted to the journal.

This is an open-access article distributed under the terms and conditions of the Creative Commons Attribution license (http://creativecommons.org/licenses/by/3.0/). 